\title{
Causes of condemnation of carcasses from poultry in slaughterhouses located in State of Goiás, Brazil
}

\author{
Causas de condenação de carcaças de aves em abatedouros localizados no Estado de Goiás, Brasil
}

\author{
Ângela Patrícia Santana ${ }^{\mathrm{I}}$ Luci Sayori Murata ${ }^{\mathrm{I}}$ Camila Guimarães de Freitas ${ }^{\mathrm{II}}$ \\ Marina Karina Delphino ${ }^{\text {II }}$ Concepta Macmanus Pimentel ${ }^{\mathrm{I}}$
}

\section{ABSTRACT}

The aim of this research was to detect the principal reasons for condemnation of poultry carcasses in two slaughterhouses (A and B); located in the southeastern region of the State of Goiás, Brazil. The data were collected by the federal veterinary inspection services of the Brazilian Ministry of Agriculture between January and April 2007. The principal causes of condemnation observed in both industries were cellulite, contusion/ fractures and bruises, as well as contamination due to gut severance at evisceration. The three main values observed for each of the causes were different between the slaughter houses. In A, cellulite was the main cause of condemnation with $51.20 \%$ of all condemnations, followed by $5.67 \%$ for contusion/ fractures and bruising and $33.61 \%$ for contamination by evisceration. In $B$, the major cause of condemnation was $28.90 \%$ due to fractures/ contusion and bruising, followed by $25.27 \%$ for cellulite and $22.50 \%$ for contamination. Other causes of condemnation were observed, however in minute quantities in both industries $(<10 \%$ to $A$ and $<23 \%$ to B). The high cellulite occurrence in A was due to the high density of the poultry in sheds (17 or 18 chickens $\mathrm{m}^{-2}$ ). The greater value for fractures/ contusion and bruising verified in $B$ was due to the inefficiency during capture in the sheds and putting on hooks in the slaughterhouse. Carcass lesions were also caused by insensitization because of non-uniformity in the poultry groups. Contamination by residues due to gut severance, mainly intestines, was attributed to problems in adjustment of machinery and non- uniformity of lots in industry A. In industry $B$ the value detected within an acceptable level of failure in evisceration for machine, according to the manufacturer. All problems observed suggest a failure in handling, cellulite and mainly failures in pre slaughter and slaughter procedure to prevent contusions, fractures and bruising.

Key words: cellulite, broiler, fractures, lesions, quality and poultry meat.

\section{RESUMO}

O objetivo deste trabalho foi observar as principais causas de condenações de aves, em dois abatedouros frigoríficos (A e B), localizados na região Sudeste do Estado de Goiás, Brasil. Os dados foram obtidos junto ao serviço de inspeção veterinária federal do Ministério da Agricultura, entre o período de janeiro e abril de 2007. As três principais causas de condenações observadas em ambas as indústrias foram celulite, contusão/fratura e hematomas e contaminação devido à ruptura de vísceras no momento da evisceração. Entretanto, os valores observados, para cada uma das causas, foram diferentes entre os frigoríficos A e B. Em A, verificou-se que a celulite foi a maior causa de condenação, com 51,20\% do total de condenações, seguido por $5,67 \%$ de contusão/fratura e hematomas e 33,61\% de contaminação na evisceração. Em $B$, a maior causa foi $28,90 \%$ para fraturas/ contusões $e$ hematomas, seguido de $25,27 \%$ para celulite e $22,50 \%$ para contaminação. Outras causas de condenação também foram observadas, porém em pequenas percentagens para ambas as indústrias. Observou-se que, em A, a celulite estava relacionada à alta densidade de aves $/ \mathrm{m}^{2}$ nos galpões (17 a 18 aves $\mathrm{m}^{-2}$ ). $\mathrm{O}$ maior índice para fratura/contusões e hematomas observados em $B$ foi relacionado à ineficiência na apanha e no enganchamento, bem como a traumas no momento da insensibilização devido à desuniformidade das aves. Para a contaminação por resíduos de rompimento de vísceras, principalmente alças intestinais, foi atribuído, para A, problemas na regulagem da máquina e desuniformidade do lote e, para $B$, o valor detectado estava dentro da margem aceitável de falhas na evisceração para a máquina evisceradora, segundo o fabricante. Os problemas verificados ainda sugerem falhas no manejo, no que se refere às celulites, e principalmente falhas nas operações de pré-abate e abate para os índices de contusões, fratura e hematomas.

Palavras-chave: celulite, frango, fraturas, lesões, qualidade e carne de aves.

\footnotetext{
IÁrea de Medicina Veterinária Preventiva. Faculdade de Agronomia e Medicina Veterinária (FAMV), Universidade de Brasília (UNB). Campus Darcy Ribeiro, CP 4508, Icc Sul, Asa Norte, 70910-970, Brasília, DF, Brasil. E-mail: patvet@unb.br. Autor para correspondência.
}

IIPrograma de Pós-graduação em Saúde Animal, FAMV, UNB, Brasília, DF, Brasil. 


\section{INTRODUCTION}

Poultry has become consolidated as the most important source of animal protein for the human population. In agreement with numbers of the United States Department of Agriculture (USDA), the worldwide poultry production grew systematically in the last thirty years, passing from 7.47 million tons in 1970 to 40 million tons by the end of the XX century. In Brazil, the growth of production, consumption and exportation were challenges which have been met at all levels. Brazilian production showed over the above period an annual average growth of $10.64 \%$ (SANTOS FILHO et al., 2000).

Brazil has come to occupy a prominent place in the world-wide poultry scene, as a highly competitive sector where the low cost of production has led to the growth of industries involved. This fact has led to a high sanitary level in breeding sector so that the companies can expect maximum performance from the birds (LEFFER, 2004). According to data from the annual report of the Brazilian Union of Poultry Keepers - UBA (2007), Brazilian production of poultry meat in 2006 reached 9.335 .546 tons, this being $0.41 \%$ larger than in 2005. This number guaranteed Brazil $3^{\text {rd }}$ place in terms of world poultry production. In terms of exportation, the country reached $2.712 .958 .727 \mathrm{~kg}$ of poultry meat, with the largest buyers being the Middle East (entire carcasses), Asia (cuts) and European Union (industrialized). This fact made Brazil the world's largest exporter of poultry meat. The destination of the production showed that $70.5 \%$ of national production goes to the domestic market, and 30\% to exports.

Sanitary problems can compromise the exportation of poultry products, so measures must be adopted to attain better results in relation to this point (CAN, 2005). Moreover, the appearance, hygiene and flavor are the main factors observed by the consumers at the moment of purchase (SILVA \& MOTA, 2003). For SILVA (2004), this panorama of quality and health was decisive for the increase of Brazilian exports of poultry meat, mainly to extremely demanding markets. In 2006, despite internal (foot and mouth disease) and external (bird flu) sanitary problems, the country registered record values in exports and commercial balance (UBA, 2007).

Many pathologies cause problems for poultry farmers because veterinary evaluation at the time of slaughter may lead to total or partial condemnation of carcasses or viscera (MAPA, 1998). Due to modifications in industrial processes, some pathologies have become more important, because they have led to an increase in the number of carcass lesions in the slaughter house and consequently in the number of animals rejected (FALLAVENA, 2003). OLIVEIRA \& CARVALHO (2002) detected a high number of lesions (2.6\%) in the sole of the foot in groups with a density of 15 chickens for square meter with different types of bedding. SILVA \& MOTA(2003) point to cellulite as the one of the greater causes of carcass rejection in slaughter houses. These same authors affirm that rejection due to cellulite is because the visual aspect the pathology causes in the carcass.

Due to the importance of the different causes of carcass rejection in slaughter houses, this study aimed to verify the main causes of carcass rejection in two industries located in the State of Goiás, Brazil between the months of January and April of 2007.

\section{MATERIAL AND METHODS}

The results of post-mortem inspection leading to total or partial rejection of carcasses were observed between the months of January and April 2007, in two slaughterhouses located in the southeastern region of the State of Goias (Brazil). During this period, data were obtained daily from the Federal Inspection staff on internal and external examination as well as examination of viscera. Federal Inspection staff was also responsible for classification of injuries in the post-mortem inspection.

The slaughterhouse 'A' and ' $B$ ' were located approximately 220 and $300 \mathrm{~km}$ of Goiânia, in the State of Goiás, respectively. The farms that supplied poultry for slaughterhouse A had eight to ten sheds with 25 thousand poultry in each shed. The ventilation was always negative. The farm that supplied slaughterhouse B had four sheds with 18 to 20 thousand poultry each. The ventilation system varied per shed (both negative and positive). There were wooden chips or rice husks on the floor of all sheds supplying both slaughter houses and a nipple system was used by all farms for food and water supply. In A, the average slaughter rate was approximately 420 thousand chickens per day, while in B, the average slaughter was approximately 70 thousand chickens per day. Both worked on the basis of integration with the production system. Therefore, all poultry came from small integrated farmers or cooperatives, which were visited to check animal density. All slaughter technologies were automated in both slaughterhouses and both followed the Brazilian Ministry of Agriculture guidelines. The descriptive analysis was used to analyze the data (HOEL, 1989). 


\section{RESULTS AND DISCUSSION}

The main causes of injuries and condemnation found in the two slaughterhouses (A and $\mathrm{B})$ are given in table 1 . Slaugtherhouse A slaughtered 40,732,773 poultry in the period between January and April. Of this total, 3,384,861 birds were rejected $(8.3 \%)$. Of these, $4.25 \%$ were because of cellulite, $0.47 \%$ were due to contusions / fractures and bruises of various causes, $2.79 \%$ due to contamination due to the breakdown of offal during the evisceration procedure, $0.32 \%$ were due to arthritis, $0.09 \%$ due to cachexia, $0.08 \%$ due to the bad bleeding, $0.06 \%$ due to the repulsive appearance and $0.24 \%$ due to other causes (Table 1). Cellulite was the major cause of condemnation in slaughterhouse A, corresponding to $4.25 \%$ of total slaughter in the period studied, resulting in $51.20 \%$ of the total birds rejected. These results corroborate the reports of SILVA\& MOTA(2003), DERAKHSHANFAR \& GHABARPOUR (2002) GOMIS et al. (1997) and MESSIER et al. (1993), in which they pointed to the occurrence of cellulite as responsible for $30 \%$ of condemnations in the slaughter of meat chickens. According to FALLAVENA (2003) lesions by cellulite are related to the occurrence of injuries, especially scratches which happen with inappropriate management practices within farming systems. These include high population density, food restriction programs and lighting, which increase competition for food.

The density of birds seen was about 17 to 18 poultry $\mathrm{m}^{-2}$, verified during the visit to the production sheds which provided chickens for slaughterhouse A.
This density is not recommended by OLIVEIRA \& CARVALHO (2002), who suggest a maximum of 15 poultry $\mathrm{m}^{-2}$. The larger number of cases of cellulite seen in slaughterhouse A may be due to the greater density of poultry observed. Other lesions found in this study were consistent with those presented by ALLAN (2004) and ODERKIRK (1997). They note that the lesions are usually located in the ventral region of the abdomen and thigh. It was found that, in establishment $\mathrm{A}$, the contamination $(2.79 \%)$ usually happened after the passage through the evisceration machine and after removal of the cloaca, which is in agreement with COSTA \& COSTA (2001). This author cites failure in regulation of equipment, the large amount of animals slaughtered daily and batches of chickens of different weights slaughtered on the same day, as the main factors responsible for carcass condemnation.

Contamination has been one of the largest problems faced by industries using mechanical eventration and automated systems. This arises from the perforation of the digestive system at the time of extraction, according to KIROV (1993) and COSTA \& COSTA(2001).

In slaughterhouse $A$, the third largest condemnation was due to contusion/fracture, which represented $0.47 \%$ of the slaughtered poultry, a relatively low number when compared to the other two causes, but high enough to be of concern when the total number of birds condemned was evaluated. According to FARSIE et al. (1983) and EKSTRAND (1998), poultry reach the processing plant with about 0.022 to $25 \%$ of contusions compared to the total slaughter, so these data of this paper are in agreement with these authors.

Table 1 - Major causes of total and partial condemnation in slaughterhouses A and B, located in the State of Goias, Brazil, in the period January to April 2007.

\begin{tabular}{|c|c|c|c|c|}
\hline \multirow[b]{2}{*}{ Total and parcial condemnation } & \multicolumn{2}{|c|}{----------Slaughterhouse A--------- } & \multicolumn{2}{|c|}{----------Slaughterhouse B---------- } \\
\hline & $\begin{array}{l}\% \text { of slaughter birds } \\
\text { rejected* }\end{array}$ & $\begin{array}{c}\% \text { causes of } \\
\text { condemnation ** }\end{array}$ & $\begin{array}{l}\% \text { of slaughter birds } \\
\text { rejected *** }\end{array}$ & $\begin{array}{c}\text { \% causes of } \\
\text { condemnation } * * * *\end{array}$ \\
\hline Cellulite & 4.25 & 51.20 & 0.91 & 25.27 \\
\hline Contusion/fracture/ bruising & 0.47 & 5.67 & 1.04 & 28.90 \\
\hline Contamination & 2.79 & 33.61 & 0.81 & 22.50 \\
\hline Arthritis & 0.32 & 3.85 & - & - \\
\hline Cachexia & 0.09 & 1.08 & - & - \\
\hline Poor bleeding & 0.08 & 0.96 & 0.02 & 0.55 \\
\hline Hepatitis & - & - & 0.31 & 8.61 \\
\hline Repugnant appearance & 0.06 & 0.72 & - & - \\
\hline Coligranuloma & - & - & 0.36 & 10 \\
\hline Other causes & 0.24 & 2.89 & 0.15 & 4.17 \\
\hline Total & 8.3 & 100 & 3.6 & 100 \\
\hline
\end{tabular}

* Total slaughtered poultry: 40,732,773** Total poultry condemned: 3,384,861*** Total slaughtered poultry: 6,457,166 **** Total poultry condemned: 235,014. 
Factors such as the method of harvesting, transport time, waiting time, type of transportation boxes, density per cage, harvesting period, age, sex and temperature were reported by FARSIE et al (1983) as parameters that influence poultry lesions. The sum of the three major causes above account for $90.88 \%$ of all condemnations in slaughterhouse A.

For slaughterhouse $\mathrm{B}$, in the period between January and April, 3.6\% of all poultry slaughtered were condemned. Here, $1.04 \%$ were due to contusions and fractures, $0.91 \%$ were due to cellulite, $0.81 \%$ were due to contamination, $0.02 \%$ due to the bad bleeding, $0.31 \%$ due to hepatitis, $0.36 \%$ due to coligranuloma and $0.15 \%$ due to other causes (Table 1).

According to GREGORY (1989), incorrect stunning before slaughter may break the blood vessels and provoke bruising, bleeding in the wings, purple discoloration in the skin, breaking bones and clots formation in the muscle of the chest of the bird. The Instruction Guidelines nº3, from January 2000 published by the Brazilian Ministry of Agriculture, Livestock and Supply, advocates for the humane slaughtering of poultry using electric insensitization. It has been difficult to obtain a standard electric stunner for universal application as each company has particular characteristics, including the weight of the poultry and batch differences such as weight.

As a result, companies adopt, as a general rule, 990 to $1010 \mathrm{~Hz}$ frequency alternating current with approximately 0.8 to 1.6 A per bird and a voltage of $35 \mathrm{~V}$ to $45 \mathrm{~V}$ (for chickens of 1.0 to $1,5 \mathrm{~kg}$ ) or 50 to $60 \mathrm{~V}$ (for chickens of 2.0 to $2.5 \mathrm{~kg}$ ). For GREGORY (1989) these values have a low impact on the physical structure of carcasses, thus minimizing the occurrence of contusions and bruising. In industry $\mathrm{B}$, the above values for stunning were used. However, great differences in weight of the birds between lots were observed. For HOLROYD (2000) the management of poultry harvesting is an important step in the production chain, directly interfering in the carcass quality.

Cellulite appears as the second major cause of condemnation corresponding to $0.91 \%$ of total slaughter. The percentage of total condemnations due to cellulite in this slaughterhouse was $25.27 \%$. The producers who supplied chickens for this industry had used 13 to 14 birds $\mathrm{m}^{-2}$ density in the growth sheds. This density is in accordance within the standard established by OLIVEIRA \& CARVALHO (2002).

Contamination of carcasses was the third major cause of condemnation in slaughterhouse B, reaching $0.81 \%$ of the total slaughter. The value obtained is within the limits expected by the companies, since the efficiency of the machine had been considered about $98 \%$, according to the manual provided by the manufacturer, in the case, Meyn ${ }^{\circledR}$ - Poultry processing solutions.

The three main causes of condemnation were overlapping in the two slaughterhouses, but with different frequencies (Figure 1). These data corroborate the results of ARMENDARIS (2006), in which the three major causes of condemnation in poultry slaughterhouses recorded in the Gerency Information Systems of the Federal Inspection Service (SIGSIF), in the years between 2003 and 2005 were contamination of the carcass, and dermatosis contusion/fracture. In the case of cellulite, there was a smaller percentage of condemnations on the slaugtherhouse B $(0.91 \%)$ in relation to the data found on the slaughterhouse A (4.25\%). This may be the result of management adopted by slaughterhouse $\mathrm{B}$, which uses lower bird densities (13-14 poultry $\mathrm{m}^{-2}$ ) when compared with A(17-18 poultry $\mathrm{m}^{-2}$ ). According to FALLAVENA(2003), high population density is a very important factor for the increase in the occurrence of skin lesions, especially by promoting contact between the birds themselves.

Contamination was higher in A than B. Along with cellulite, which was the largest issue in the total condemnations in slaughterhouse A, these were responsible for $84.92 \%$ of all condemnations in this industry. This result may be due to the high number of birds slaughtered daily by A (420 thousand) and the speed of slaughter (160 birds min $^{-1}$ ), while in B the number of poultry slaughtered daily was 65 thousand and the average speed of slaughter is 135 poultry min $^{-1}$.

COSTA \& COSTA(2001) cite the mechanical eventration process as of paramount importance to the chicken industries, due to the large number of animals slaughtered every day and a system collapse which makes regulation of equipment a constant necessity. Because different groups of chickens are slaughtered with different weights on the same day, increasing the number of condemnations through contamination due to lack of adjustment becomes evident.

The numbers of contusions/fractures in B were higher than in $\mathrm{A}$. These were also the biggest cause of condemnation in B, with $28.9 \%$ of total condemnations, while A had $5.67 \%$ of total poultry condemned. In addition to the economic losses as a result of the fact that carcasses could not be packaged and marketed due to quality issues (ALVES, 2006), the high number of fractures and contusions are a serious problem for the meat industry and for animal welfare, as well as aiding the processes that lead the physical injuries, such as inadequate management during the chicken rearing, harvesting, processing and inappropriate transport of the poultry (ALVES, 2006; 


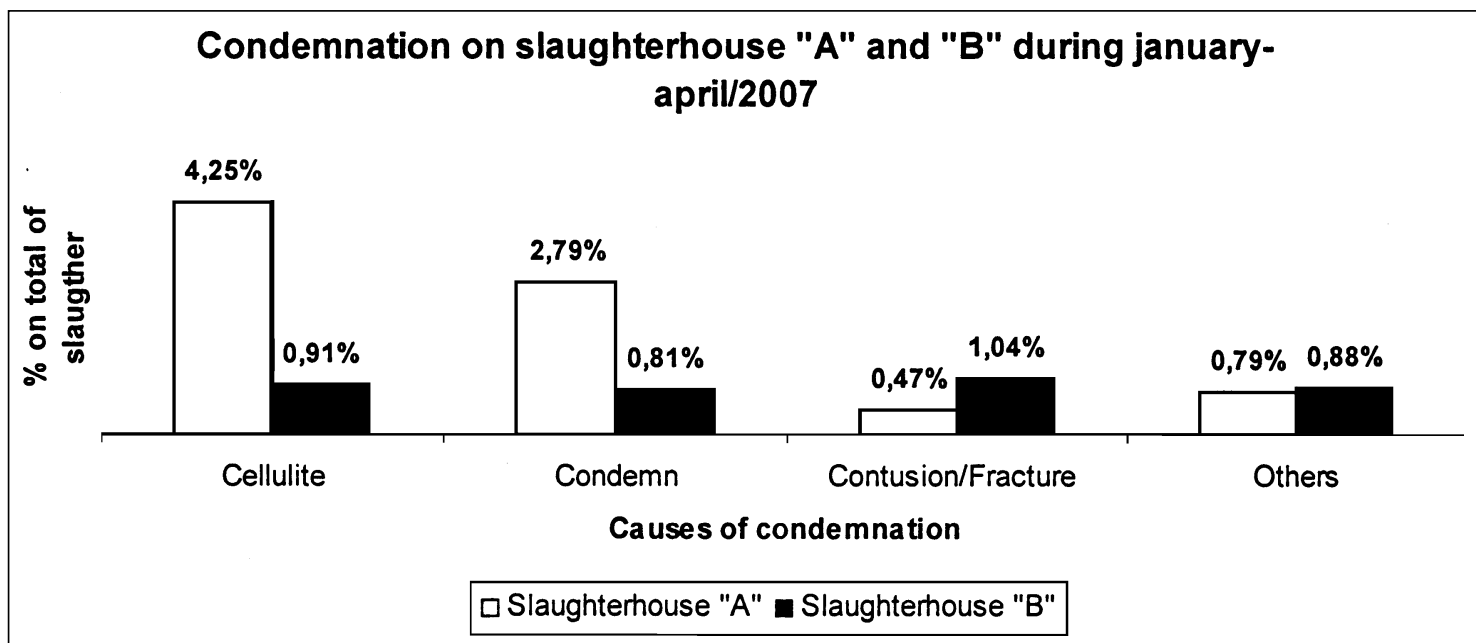

Figure 1 - Frequence of the condemnation on slaughterhouse A and B during January-April/2007.

MONDELLI, 2000). Also in B, it was observed the high number of the condemnation by the hepatitis $(8,61 \%$ of the all the condemnation) and coligranuloma ( $10 \%$ of the all the condemnation), but in this study the etiology of these pathologies was not determined.

\section{CONCLUSIONS}

Cellulite can be regarded as one of the most important causes of condemnation of meat chickens worldwide, awakening interest in terms of the economical losses it carries for producers. The losses with contusions and fractures can be reduced by improving the management of harvesting and transportation as well as the adjustment of the equipment used at slaughter. The sanitary control and operational management of slaughterhouses should be improved, since they are crucial in the quality of the final product and chicken population density greater than 15 poultry $\mathrm{m}^{-2}$ is not recommended. Finally, more studies should be performed in a way to control and minimize the losses by condemnation in refrigerators for the slaughter of chickens.

\section{REFERENCES}

ALLAN, B. Identification and characterization of the causative agent of a new type of cellulites in turkeys. 2004. Access: 03 feb 2007. Online. Avaiable at <http:// www.westvet.com/cellulitis.htm.>

ALVES, C. Análise crítica das principais causas de condenação de carcaças nos abatedouros brasileiros. In: SEMINÁRIO INTERNACIONAL DE AVES E SUÍNOS - AVESUI, 5., 2006, Florianópolis, SC - Brasil. Anais... Access: 16 jun 2007. Available at: < www.cnpsa.embrapa.br/sgc/sgc_publicacoes/ publicacao_i6s29s6x.pdf >
ARMENDARIS, P. Abate de aves - dados de condenações Serviço de Inspeção Federal. In: SIMPÓSIO DE SANIDADE AVÍCOLA DA UFSM, 5., 2006, Santa Maria, RS - Brasil. Anais... Access: 19 mar 2007. Online. Available at: $<\mathrm{h} \mathrm{t} \mathrm{t} \mathrm{p} \mathrm{:} \mathrm{/} \mathrm{/} \mathrm{w} \mathrm{w} \mathrm{w} \mathrm{.} \mathrm{c} \mathrm{n} \mathrm{p} \mathrm{s} \mathrm{a.e} \mathrm{m} \mathrm{b} \mathrm{r} \mathrm{a} \mathrm{p} \mathrm{a} \mathrm{.} \mathrm{b} \mathrm{r} \mathrm{/}$ down.php?tipo=publicacoes $\&$ cod_publicacao $=880>$

MAPA - Ministério da Agricultura, Pecuária e Abastecimento. Portaria no 210, de 10 de novembro de 1998. Aprova o regulamento técnico da inspeção tecnológico e higiênico-sanitária de carne de aves. Diário Oficial da República Federativa do Brasil, Brasília, DF, 1998.

CAN. J. Biossegurança e cuidados sanitários para frangos. Veterinary Research, 2005. Access: 20 apr 2007. Online. Available at: <http://www.avisite.com.br/cet/1/02/index.shtm

COSTA, P.S.; COSTA, L.A.S. Avaliação técnica higiênico-sanitária dos equipamentos automáticos de abate de aves de corte utilizados no Brasil. Revista Higiene Alimentar, v.17, n.104/ 105, p.46, 2001.

DERAKHSHANFAR, A.; GHANBARPOUR, R. A study on avian cellulitis in broiler chickens. Veterinary Archive, v.72, p.277-284, 2002.

EKSTRAND, C. An observational study of the effects of catching method on carcase rejection rates in broilers. Animal Welfare, v.7, p.87-96, 1998.

FALLAVENA, L.C.B. Lesões cutâneas em frangos de corte. Revista Sanidade Avícola, Porto Alegre, 2003. Access 13 apr 2007. Online. Available at: <http://www.avisite.com.br/ cet/1/04index.shtm>.

FARSIE, A. et al. Mechanical harvest of broilers. Trans ASAE, v.26, p.1650-1653, 1983.

GOMIS, S. et al. Experimental reproduction of Escherichia coli cellulites and septicemia in broiler chickens. Avian Disease, v.41, p.234-240, 1997.

GREGORY, N.G. Stunning and slaughter. In MEAD, G.C. (Ed.). Processing of poultry. London: Elsevier Applied Science, 1989. p.31-36. 
HOEL, P.G. Estatística elementar. São Paulo: Atlas, 1989. 430p.

HOLROYD, P. Tendências do mercado de carne de aves e tipo de frango para o novo milênio. In: CONFERÊNCIA APNICO DE CIÊNCIA E TECNOLOGIA AVÍCOLA, 2000, Campinas. Anais... Campinas: FACTA, 2000. p.95-109.

KIROV, S.M. The public health significance of Aeromonas spp in foods. International Journal Food Microbiology, v.20, p.179-198, 1993.

LEFFER, E.V.B. Considerações sobre o controle da doença de Gumboro. Animal World, ano 2, n.9, p.01-16, 2004. (Edição Especial).

MESSIER, S. et al. Focal dermatitis and cellulitis in broiler chickens: bacteriological and pathological findings. Avian Disease, v.37, p.839-844, 1993.

MONDELLI, G. Importância do emprego das técnicas de abate humanitário para os consumidores de carnes e frigoríficos. 2000. 168f. Monografia (Medicina Veterinária) - Universidade Sagrado Coração, Bauru, SP.

ODERKIRK, A. Broiler cellulitis. Poultry fact Sheet, Nova Escócia, canadá: Poultry Service Industry, 1997. Access: 21 mar 2007. Online. Available at: <http://www.gov.ns.ca/nsaf/ elibrary/archive/lives/poultry/broilers/celulite>.

OLIVEIRA, M.C. CARVALHO, I.D. Rendimento e lesões em carcaça de frangos de corte criados em diferentes camas e densidades populacionais. Ciência Agrotécnica, v.26, n.5, p.1076-1081, 2002.

SANTOS FILHO, J.I. et al. A avicultura brasileira na virada do milênio. Embrapa suínos e aves. Access: 20 apr 2007. online. Available at: <http://www.cnpsa.embrapa.br/?/artigos/2000/ artigo-2000-n039.htm;ano=2000> .

SILVA, E.N.; MOTA, M.P. Celulite em frangos de corte. 2003. Access: 15 apr 2007. Online. Available at: <http:// www.fatec.com.br/trabtec/celulite_em_frangos_de_corte.htm>.

SILVA, E.N. Efeito das doenças infecciosas na qualidade da carne de frangos. In: CONFERENCIA APINCO 2004 DE CIÊNCIA E TECNOLOGIA AVÍCOLAS, Santos. Anais... Santos: FACTA, 2004. p.193-199.

UBA. União Brasileira de Avicultura. Últimos números da avicultura brasileira 2007. Access: 13 may 2007. Online. Available at: <http://www.uba.org.br/index.htm>. 